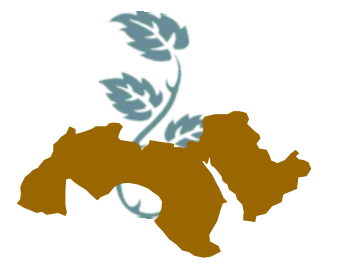

Arab Univ.

J. Agric. Sci., Ain Shams Univ., Cairo, 26(2), 581 - 598, 2018

\title{
INFLUENCE OF $\alpha$-AMYLASE AND ASCORBIC ACID COMBINATION ON EXTENSOGRAPH OF WEAK WHEAT FLOUR DOUGH AND SENSORY PROPERTIES OF PAN BREAD
}

\author{
Shebl, M.S.M.; Y.F.M. Kishk; A.A. Abd El-Fatah and E.I. Yousif \\ Food Science Dept., Fac. of Agric., Ain Shams Univ., Cairo, Egypt \\ Corresponding Author: Yasser F.M. Kishk Email: yasser keshk@agr.asu.edu.eg
}

Keywords: Pan bread, Weak flour, a-amylase, Ascorbic acid and Extensogram

\begin{abstract}
The response of different concentrations of $\alpha$ amylase and ascorbic acid on rheological characteristics of weak wheat flour was studied by the three dimension polynomial quaternary model. Flour physicochemical characteristics, dough extensogram, bread texture profile analysis and sensory properties of pan bread were determined. Allpurpose flour was treated by fungal $\alpha$-amylase and ascorbic acid compared with strong flour which using for pan bread production, and then investigates differences of dough extensograms and pan bread quality characteristics. Predicting individual extensograph parameters $(Y)$ was assumed by quadratic polynomial regression model for the independent variables (fungal $\alpha$-amylase concentrations or ascorbic acid concentrations $(X))$ to optimize the extensograph parameters $(Y)$ used regression analysis. Three-dimension contour plot was used as a method to study the response surface of different extensograph parameters $(Y)$ as dependent variables with fungal $\alpha$-amylase concentration and ascorbic acid concentration ( $X$ and Z) as independent variables. The obtained optimum predicting concentrations were verified, by using applied extensograph trials and then manufacturing pan bread. Using optimal predictive fungal $\alpha$-amylase and ascorbic acid concentration levels give accepted extensogram parameters relationship $r^{2}$ values and good pan bread quality, fit to the strong flour characteristics.
\end{abstract}

\section{INTRODUCTION}

Wheat (Triticum aestivum L.) is one of the most important crops and has been used worldwide as a main ingredient in bread making. The increasing mechanization of the baking industry and the demand for a wide range of bread types has determined the necessity to modulate structure and viscoelastic properties of dough (Dunnewing et al 2002). In modern baking industry with high demands for bread with superior nutritional and sensorial quality, using additives like enzymes and ascorbic acid are necessary to modulate the rheological properties of dough (Paucean et al 2016).

Recently microbial amylases commercially are available and almost completely replaced chemical hydrolysis of starch in starch processing industry (Pandey et al 2003). Amylases hydrolyze starch molecules to give diverse products including dextrins and progressively smaller polymers composed of glucose units (Windish and Mhatre 1965). The increase of proportion of low molecular weight fragments by amylase enzyme those characterized by lower rates of retrogradation improved the baking quality (Palacios et al 2004). Fungal $\alpha$ amylases modify the functionality of starch during baking by reducing their moisture binding capacity thus allowing more moisture to be available for gluten hydration (Martinez-Anaya and Jimenez, 1997). Fungal $\alpha$-amylase produces greater uniformity in dough properties and bread quality (Rouau et al 1994).

Ascorbic acid is widely used as a flour improver in bread products. It is generally recognized as safe (GRAS) status (U.S. Food and Drug Administration, 2006) and is a very popular flour improver. Loaf volumes increased when dough contain ascorbic acid (Aamodt et al 2003 and Koehler, 2003). Ascorbic acid strengthens the gluten matrix due to the density of di-sulphide bonds in gluten. However, stronger gluten leads to higher loaf volumes (Larsson and Eliasson, 1996). Addition of a-amylase and ascorbic acid are key drivers for rheological and baking qualities of wheat flour 
dough (Patel et al 2012).Ascorbic acid caused a significant increment of specific volume (Paucean et al 2016).

The manuscript aimed to determine the optimum a-amylase and ascorbic acid concentrations can be used to prepare pan bread using weak flour. Study the effect of treatment on the rheological characteristics of dough. Investigate the effect of the treatment on the pan bread characteristics. All determinations on the dough or bread carried out compared to the strong flour dough or bread.

\section{MATERIALS AND METHODS}

\section{Materials}

All-purpose flour (Semi-hard commercial Russian wheat flour) obtained from Amoun for Milling Company, Giza, Egypt. Strong flour (commercial Australian wheat flour) obtained from the local market produced by Five Stars Milling Company, Suisse, Egypt. Purified fungal (Aspergillus oryzae) a-amylase 90000 SKB obtained from Novozymes Company, Switzerland. Standardized ascorbic acid (purity $>99 \%$ ) provided from Muhlenchemie $\mathrm{GmbH}$ Company, Ahrensburg, Germany. Instant active dry yeast (Saccharomyces cerevisiae), Angel Yeast, Co., Ltd., Beni Suef Egypt. Crystal white sugar, salt and vegetable oil were obtained from local market, Cairo, Egypt.

\section{Methods}

\section{Physicochemical characteristics}

Moisture, ash, protein $(\mathrm{N} \times 5.7)$ and total lipid analyses carried out according to AACC International, 2012. The nitrogen free extract (NFE) was calculated by differences. Wet and dry gluten were determined according to AACC International, 2012 Method 38-12.02.

The falling number determined by FN 1500 (Perten instruments $A B$, Hagersten, Sweden) according to AACC International method 56-81.03. Starch damage determined by SD Matic, Chopin Technologies, France according AACC International method 76-33.01.

\section{Extensograph test}

Dough properties were evaluated using Brabender extensograph (Brabender $\mathrm{GmbH}$, Duisburg, Germany) according to ICC (2012). Extensograph test was carried out to determine resistance to extension (BU), maximum resistance to extension $(B U)$, extensibility $(\mathrm{mm})$, ratio number $(\mathrm{RN})$, ratio number (Max.) and Energy $\left(\mathrm{cm}^{2}\right)$.

\section{Preparation of pan bread}

The used recipe to prepare untreated pan bread was $1 \mathrm{Kg}$ flour (72\% ext.), farinograph water absorption plus $20-40 \mathrm{~g}$ that depends on optimum consistency $20-40 \mathrm{~g}$ water (according farinograph water absorption that depends on optimum consistency), $20 \mathrm{~g}$ dry yeast, $10 \mathrm{~g}$ sugar and $10 \mathrm{~g}$ salt (AACC International Method, 2012). a-amylase or/and ascorbic acid added directly to the flour to prepare the treated pan bread. The flour was added in the mixing bowl then adding rest of the ingredients. Mixer well be at low speed $80 \mathrm{rpm} \mathrm{min}^{-1}$ for $4 \mathrm{~min}$ (Diosnaspiral mixer), then mixing at fast speed $150 \mathrm{rpm} \mathrm{min}{ }^{-1}$ for 4-6 min. till optimum development dough. Then all ingredients well mixed to elastic dough. The dough rested at room temperature $\left(25 \pm 2^{\circ} \mathrm{C}\right)$ for $10 \mathrm{~min}$, and then divided into pieces (300 g per piece), rounded, then molded into desired length and placed into the greased baking pans $(25 \times 7.5 \times 6.5 \mathrm{~cm})$. The dough fermented in proofing cabinet was done (Mac. pan Bakery Machines and Equipment, Italy) at $33^{\circ} \mathrm{C}$ and relative humidity $85 \%$ for $90 \mathrm{~min}$. The dough was baked without oven steam at $230^{\circ} \mathrm{C}$ for $20 \mathrm{~min}$. in an electric oven (MIWE econo, MIWE Michael Wenz GmbH, Arnstein, Germany). Pan bread cooled to room temperature $\left(25 \pm 2^{\circ} \mathrm{C}\right)$ for $2 \mathrm{~h}$. The bread was sliced to $1 \mathrm{~cm}$ of thickness (mac. pan Slicing machine model MPT 400, Italy). The prepared pan bread was packed in polyethylene bags, and then stored at room temperature $\left(25 \pm 2^{\circ} \mathrm{C}\right)$ for 3 days.

\section{Texture profile analysis}

The Texture Profile Analysis (TPA) of pan bread was carried out by Texture Analyzer TVT300XP (TexVol Instruments AB, Viken, Sweden) according to Pons and Fiszman (1996). The instrument was equipped with a $5 \mathrm{~kg}$ load cell. A cylindrical probe of $36 \mathrm{~mm}$ in diameter was attached to the cross head (Type: P-Cy $36 \mathrm{R}$ ). The instrument test parameters were set as following: Test mode: Multiple cycles: 2; Rig: No Rig; approx. height: $50 \mathrm{~mm}$; Compression: 40\%; Trigger force: $5 \mathrm{~g}$; pre-test speed: $1.0 \mathrm{~mm} / \mathrm{s}$; test speed: 1.0 $\mathrm{mm} / \mathrm{s}$; post-test speed $10.0 \mathrm{~mm} / \mathrm{s}$; Data Acquisition Rate: 200 pps; Diameter: $15 \mathrm{~mm}$; Height: $50 \mathrm{~mm}$; Headroom above object: $5 \mathrm{~mm}$; Force unit: g; Headroom above Trigger: $0 \mathrm{~mm}$; Pause in between cycles: 0 s; Function of: Time; Bread slice: 2 
equal $20 \mathrm{~mm}$ height; Area $\left(100 \mathrm{~cm}^{2}\right)$ operated at: 0-100g. Hardness, springiness, cohesiveness, adhesiveness, chewiness, gumminess and resilience were obtained from analysis of pan bread.

\section{Color measurement}

Brightness $\left(L^{*}\right)$, redness $\left(a^{*}\right)$ and yellowness $\left(b^{*}\right)$ of pan bread crust and crumb were analyzed with a colorimeter (Konica Minolta CR-410 Chroma meter, Sensing, INC., Japan)) according to Tong et al (2010). $L^{*}$ values represent brightness on a 0 (pure black) -100 (pure white) unit scale, $a^{*}$ values range from -60 (pure green) to +60 (pure red) and $b^{*}$ values range from -60 (pure blue) to +60 (pure yellow). Each $L^{*}, a^{*}$ and $b^{*}$ value printed is averaged from three readings.

\section{Sensory evaluation}

Quality attributes of prepared pan bread were evaluated after cooling for $2 \mathrm{~h}$ from baking at room temperature $25 \pm 2^{\circ} \mathrm{C}$ (zero time) then, every $24 \mathrm{~h}$ till $72 \mathrm{~h}$. The evaluation carried out by ten experienced panelists from the staff of Amoun for Milling and Chmiteczymes Co. Crust color, symmetry, crumb color, pore size, uniformity of pore size, taste and overall acceptability were evaluated according to the 1-9 hedonic scale. The scale had verbally anchored with nine categories as follows: like extremely, like very much, like moderately, like slightly, neither like or dislike, dislike slightly, dislike moderately, dislike very much and dislike extremely (Larmond, 1970). Quality attributes of treated pan breadwere evaluated in comparison with the negative control or positive control samples, which were prepared from weak or strong flour.

\section{Specific volume}

Loaf weight $(\mathrm{g})$, loaf volume $\left(\mathrm{cm}^{3}\right)$ and specific volume $\left(\mathrm{cm}^{3} / \mathrm{g}\right)$ of pan bread were calculated according to AACC International, 2012 method 1005.01; Guidelines for measurement of volume by rapeseed displacement. Specific volume $\left(\mathrm{cm}^{3} / \mathrm{g}\right)$ was calculated by dividing volume of the loaf by its weight. Loaf weight $(\mathrm{g})$ was recorded after cooling for $2 \mathrm{~h}$. Loaf volume $\left(\mathrm{cm}^{3}\right)$ was measured by rape seed displacement.

\section{Staling characteristics of pan bread}

Staling rate of pan bread samples was determined using penetrometer apparatus, compared to sensory evaluation according to Shah et al (2006). Pan bread was stored for 24, 48 and $72 \mathrm{~h}$ in sealed polyethylene bags at room temperature $(25$ $\pm 2{ }^{\circ} \mathrm{C}$ ). Thickness of sample slice was $1 \mathrm{~cm}$. A part of $2.5 \mathrm{~cm}$ must be cutting and discarding from the bread from the front and end of the loaf.

\section{Statistical analysis}

Predicting individual extensograph parameters (Y) was assumed by quadratic polynomial regression model for the independent variables (fungal $\alpha$ amylase concentrations or ascorbic acid concentrations $(X))$ to optimize the extensograph parameters $(Y)$ used regression analysis. The model proposed for response of $\mathrm{Y}$ as follows:

$$
Y=y_{\circ}+a x+b x^{2}
$$

Where, $\left(\mathrm{y}_{\mathrm{o}}\right),(\mathrm{a})$ and (b) are intercept, linear and quadratic regression coefficient terms, respectively and $X$ is independent variable. Analysis of variance (ANOVA) was used with the obtained data. Duncan multiple ranges at $5 \%$ level of significance was used according to Duncan (1955) to compare between means. Results followed by different alphabetical letters significantly differed. ANOVA analysis was carried out using the PROC ANOVA procedure of Statistical Analysis System (SAS, 2000). Three-dimension contour plot was used as a method to study the response surface of different extensograph parameters $(Y)$ as dependent variables with fungal $\alpha$-amylase concentration and ascorbic acid concentration ( $X$ and $Z$ ) as independent variables. The response surface methods was applied using Sigma Plot program (2014) to locate the optimum fungal $\alpha$-amylase and ascorbic acid concentrations to obtain the optimum extensograph parameters that can produce high quality pan bread. The model proposed for Threedimension response surface of $Y$ as follows:

$$
\begin{array}{r}
Y=y_{\circ}+a x+b z+c x^{2}+d z^{2}+e x^{3}+g z^{3}+h x^{4}+i z^{4} \\
+j x^{2} z^{2}+k x^{3} z^{3}+l x^{4} z^{4}
\end{array}
$$

\section{RESULTS AND DISCUSSION}

\section{Physicochemical characteristics}

The moisture, protein, total lipid, ash, nitrogen free extract (NFE), wet gluten, dry gluten, gluten index, falling number and starch damage contents of weak wheat flour and strong wheat flour are shown in Table 1. The results revealed that non- 
significantly $(P \geq 0.05)$ differences between wheat flours in moisture content which were $13.5 \%$ (moisture related to flour shelf life because excessive moisture leads to probably un useful microorganisms growth, the second reason, the relation with flour extraction efficiency). The concentration of protein (protein content and quality related to the gluten content and grain hardness which reflex on milling design process and it's end products, ash and nitrogen free extract (NFE) were significantly $(P \leq 0.05)$ higher in strong flour than in weak flour because of milling process variation and plant strain differences. On the contrary, the weak wheat flour significantly had slight high total lipid content compared to strong flour were 1.11 and $1.02 \%$, respectively. Also the wet and dry gluten concentrations positively affected in strong flour according to protein content (gluten content related to end product quality depends on gluten network properties and it's gas retention capacity, also hence water absorption and dough handling when high content). The strong flour had 32.4 and $13.3 \%$ of wet and dry gluten with significantly higher values than weak flour (25.8 and $12.7 \%)$. Non-significant difference was observed between weak and strong flour in gluten index was 96 and 91, respectively.

Table 1. Physicochemical characteristics of weak and strong flour

\begin{tabular}{|c|c|c|}
\hline Properties & Weak flour & Strong flour \\
\hline Moisture & $13.5^{\mathrm{a}}$ & $13.5^{\mathrm{a}}$ \\
* Protein N= 5.7 & $10.6^{\mathrm{b}}$ & $13.5^{\mathrm{a}}$ \\
* Total lipids & $1.11^{\mathrm{a}}$ & $1.02^{\mathrm{b}}$ \\
* Ash & $0.53^{\mathrm{b}}$ & $0.56^{\mathrm{a}}$ \\
* NFE & $87.76^{\mathrm{b}}$ & $84.92^{\mathrm{a}}$ \\
** Wet gluten & $25.8^{\mathrm{b}}$ & $32.4^{\mathrm{a}}$ \\
${ }^{* *}$ Dry gluten & $12.7^{\mathrm{b}}$ & $13.3^{\mathrm{a}}$ \\
Gluten index & $96^{\mathrm{a}}$ & $91^{\mathrm{a}}$ \\
** Falling number (Sec.) & $389^{\mathrm{a}}$ & $363^{\mathrm{b}}$ \\
Starch damage & $5.4^{\mathrm{b}}$ & $5.6^{\mathrm{a}}$ \\
\hline
\end{tabular}

Means in the same row with different letters are significantly different $(P \leq 0.05)$

* Dry base, ${ }^{* *} 14 \%$ moisture base

NFE- Nitrogen free extract

The falling number was lower in strong flour than in weak flour with values were 389 and 363 sec., respectively (high falling number refers to internal low $\alpha$-amylase activity, leads to longer fermentation time, lower loaf volume and lower crust color). The starch damage was 5.4 and 5.6 in each of weak and strong flours with significant dif- ference $(P \leq 0.05)$, excess starch damage percent lead to sticky dough. The previous data were agreed with those finding by Gomes-Ruffi et al (2012); Colakoglu et al (2012) and Kaltsa et al (2013).

\section{Effect of $\alpha$-amylase concentration on the ex- tensograph parameters}

The effect of different concentrations from fungal $\alpha$-amylase on the extensograph parameters of weak wheat flour was presented as quadratic polynomial trends in Fig. 1. The fungal $\alpha$-amylase concentration was ranged between 0 to $15 \mathrm{ppm}$. The $\alpha$-amylase concentration had a significant $(P \leq 0.05)$ effect on the extensograph parameters. Resistance increased from 401 to $574 \mathrm{BU}$ with increasing the $\alpha$-amylase concentration from 0.0 to $15 \mathrm{ppm}$. Equation 3 was used to predict the resistance behavior. Lowest and highest predicted resistance values were 392 and $576 \mathrm{BU}$ at $\alpha$ amylase concentrations 2.26 and 15 ppm. According to Equation 4 the extensibility gradually increased from $157 \mathrm{~mm}$ at $0.0 \mathrm{ppm}$ a-amylase to the maximum level was $165 \mathrm{~mm}$ at $5.21 \mathrm{ppm} \alpha-$ amylase, and then dramatically decreased to the minimum value $137 \mathrm{~mm}$ at $15 \mathrm{ppm} \alpha$-amylase. Maximum resistance changes affected by $\alpha-$ amylase added as the equation 5 appeared. Kim et al (2006) reported that the addition of fungal $\alpha$ amylase resulted in a decrease of energy and in an increase of resistance for all samples tested. Therefore, the ratio of resistance/energy for dough samples containing fungal $\alpha$-amylase significantly increased as compared with those without fungal a-amylase.

The non-treated dough ( $0.0 \alpha$-amylase) showed low maximum resistance value $599 \mathrm{BU}$. On the other hand using the a-amylase enzymes lead to enhance the dough maximum resistance. However, the maximum resistance was increased with increasing the $\alpha$-amylase concentration to 14.8 ppm with value $781 \mathrm{BU}$. Equation 6 discussed the effect of $\alpha$-amylase concentration on the ration number. The same trend in resistance figure was observed. At the beginning, the ratio number decreased with increasing the $\alpha$-amylase enzyme. From the output data from Equation 6, at the $\alpha$ amylase concentration $5.7 \mathrm{ppm}$ the ration number started with increasing. The maximum ratio number was observed at the maximum $\alpha$-amylase concentration used. The ratio number was 4.19 at 14.8 ppm $\alpha$-amylase. Increasing $\alpha$-amylase concentrations lead to increasing the energy area in the dough samples. Fungal $\alpha$-amylases depolymerise damaged starch and reduced its ability to bind 

flour dough and sensory properties of pan bread

moisture, thus allowing more moisture to be available for gluten hydration. It gives a reason to more gluten development then more enhancement extensograph parameters, Martinez-Anaya and Jimenez (1997). But this resultedin nonlinear relation between the a-amylase and energy. According to the polynomial trend that obtained from equation $7\left(r^{2}=0.8020\right)$ the maximum energy was $138.7 \mathrm{~cm}^{2}$ at $10.3 \mathrm{ppm} \alpha$-amylase. Increasing the $\alpha$-amylase concentration more than $10.3 \mathrm{ppm}$ leads to gradually decreasing the energy to $135.4 \mathrm{~cm}^{2}$ at $15 \mathrm{ppm}$ $\alpha$-amylase concentration. Equation $8\left(r^{2}=0.9995\right)$ presented the quadratic polynomial trend of maximum ratio number. Equation 8 gave the same trend that in ratio number parameter with some differences in the $\alpha$-amylase concentrations. Regression coefficients were presented in Fig. 1 to predict quadratic polynomial models for extensograph parameters. The models were tested for adequacy by analysis of variance. The regression models for data were highly significant $(P \leq 0.05)$ with determination coefficients ranged between 0.8020 and 0.9997 .

Consequently, the obtained predicted models showed the enhancement in the dough behavior with the different $\alpha$-amylase concentrations, but it could not use the $\alpha$-amylase alone to prepare suitable dough with ideal extensograph parameters from weak flour to prepare pan bread. Therefore, it was necessary to study the effects of ascorbic acid on the extensograph parameters in a trial to obtain the optimum conditions to prepare the pan bread from weak flour.

\section{Effect of ascorbic acid concentration on the extensograph parameters}

Ascorbic acid showed good effects on the extensograph parameters of weak flour dough. Ascorbic acid enhanced the extensograph parameters compared to the a-amylase enzyme. Both of resistance and maximum resistance were increased with increasing the ascorbic acid concentration from 0.0 to $60 \mathrm{ppm}$ with higher increasing rates than were observed with using $\alpha$-amylase enzyme. It is acknowledged that ascorbic acid strengthens the gluten matrix by increasing the density of di-sulphide bonds in gluten (Aamodt et al 2003 and Koehler, 2003). The -SH radicals reassociate and form intermolecular -SS- bonds with concomitant improvement of bread structure, Miyamoto and Nishimura (2006). Tilley et al (2001) showed that dehydro ascorbic acid can also cross link proteins through linkages other than SS- bonds. They observed an increased formation of dityrosine linkages after dough mixing and baking when ascorbic acid was added. According to the output data from polynomial quadratic equations 9 and 11 the maximum values of resistance and maximum resistance 960 and 1113 BU were observed at ascorbic acid concentration $90 \mathrm{ppm}$. The rate of increased with the ascorbic acid at 90 ppm were 40 and $29 \%$ for resistance and maximum resistance compared to $\alpha$-amylase enzyme at $15 \mathrm{ppm}$. The extensibility took different trend compared to the obtained extensibility curve using $\alpha$-amylase enzyme. According to equation 10 the extensibility dramatically decreased to the lowest value $99.4 \mathrm{~mm}$ at the maximum ascorbic acid concentration was used ( $90 \mathrm{ppm})$. It could be concluded that, ascorbic acid had higher effect on the dough extensibility behavior than a-amylase enzyme. Regression of the ratio number and maximum ratio number data gave a linear trend (Eq. 12 and 14) with $r^{2}=0.9665$ and 0.9756 . The ratio number increased from 2.6 to 9.7. At the same time the maximum ratio number increased from 3.9 to 11.2. Both of the ratio number and maximum ratio number had fold values compared to the same treatment with using $\alpha$-amylase enzyme. From the polynomial regression data that obtained energy value from equation $13\left(r^{2}=0.5093\right)$ gradually increased to the maximum value. The maximum energy value was $143.1 \mathrm{~cm}^{2}$ at $47.8 \mathrm{ppm}$ ascorbic acid. Then, with increasing the ascorbic acid concentration more than $47.8 \mathrm{ppm}$ the energy value gradually decreased. The obtained energy trend from using ascorbic acid gave slightly higher effect than using a-amylase enzyme. Hruskova and Novotna (2003) investigated the effect of ascorbic acid dough extension tests (measured by the extensograph). Ascorbic acid being itself a reducing agent can exert an oxidizing effect on the dough properties after its oxidation by atmospheric oxygen. The oxidation product, dehydro-L-ascorbic acid can oxidize glutathione under the influence of a specific enzyme.

The obtained models can be used to help understand the kinetics effects of $\alpha$-amylase enzyme or ascorbic acid on the extensograph parameters of weak flour dough. The models were produced from data regression gave highly significant $(P \leq 0.05)$ with determination coefficients ranged between 0.5093 and 0.9849 . 

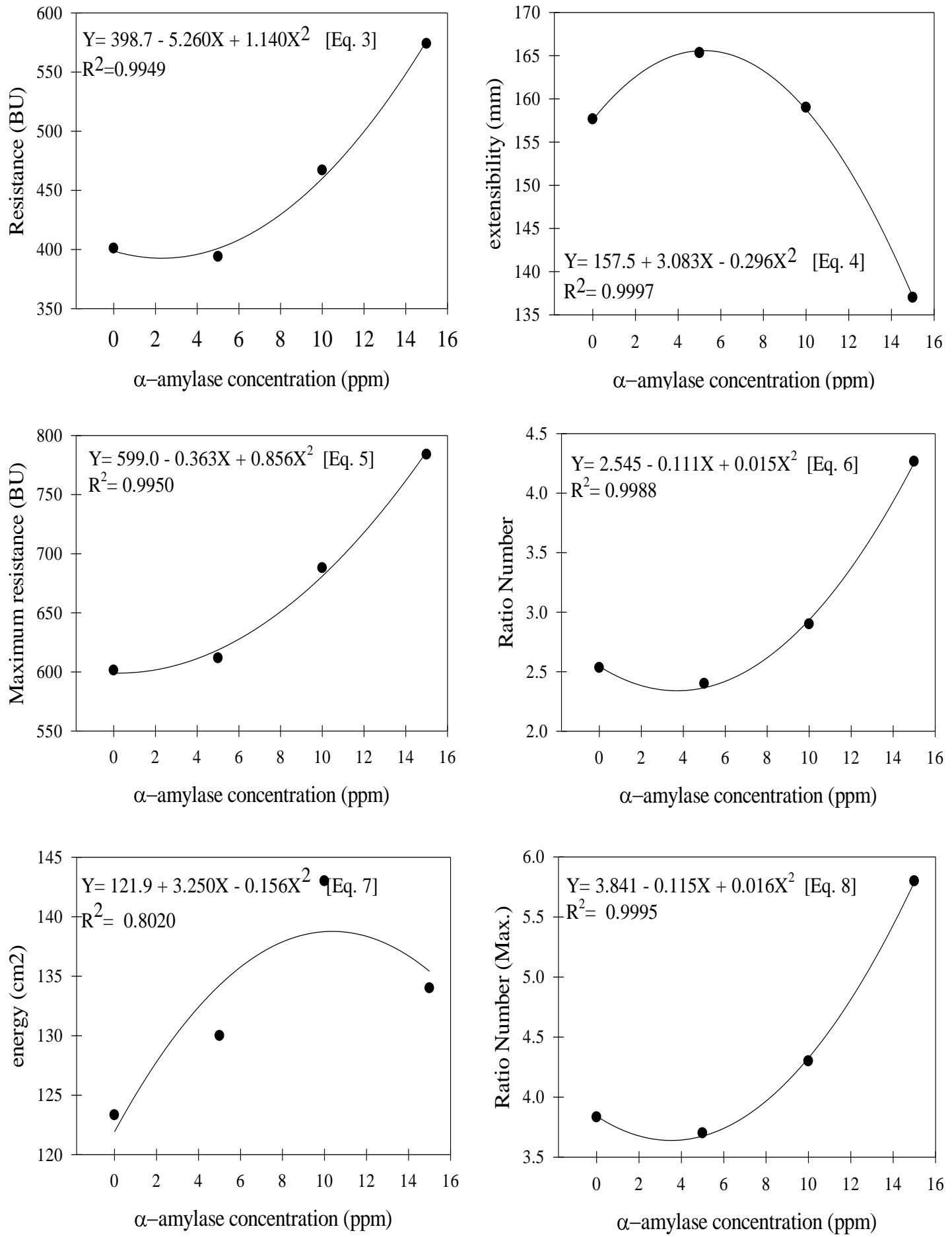

Fig. 1. Polynomial Quadratic trend of $\alpha$-amylase concentration (ppm) versus the extensogram parameters at zero level of ascorbic acid. 


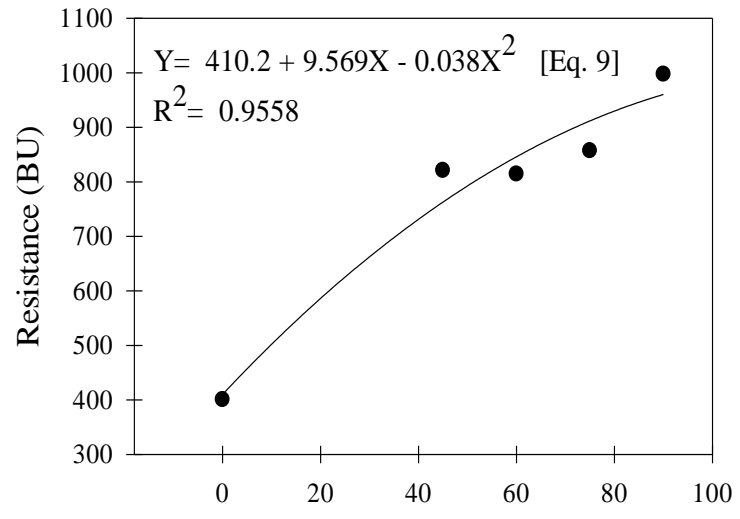

Ascorbic acid concentraton (ppm)
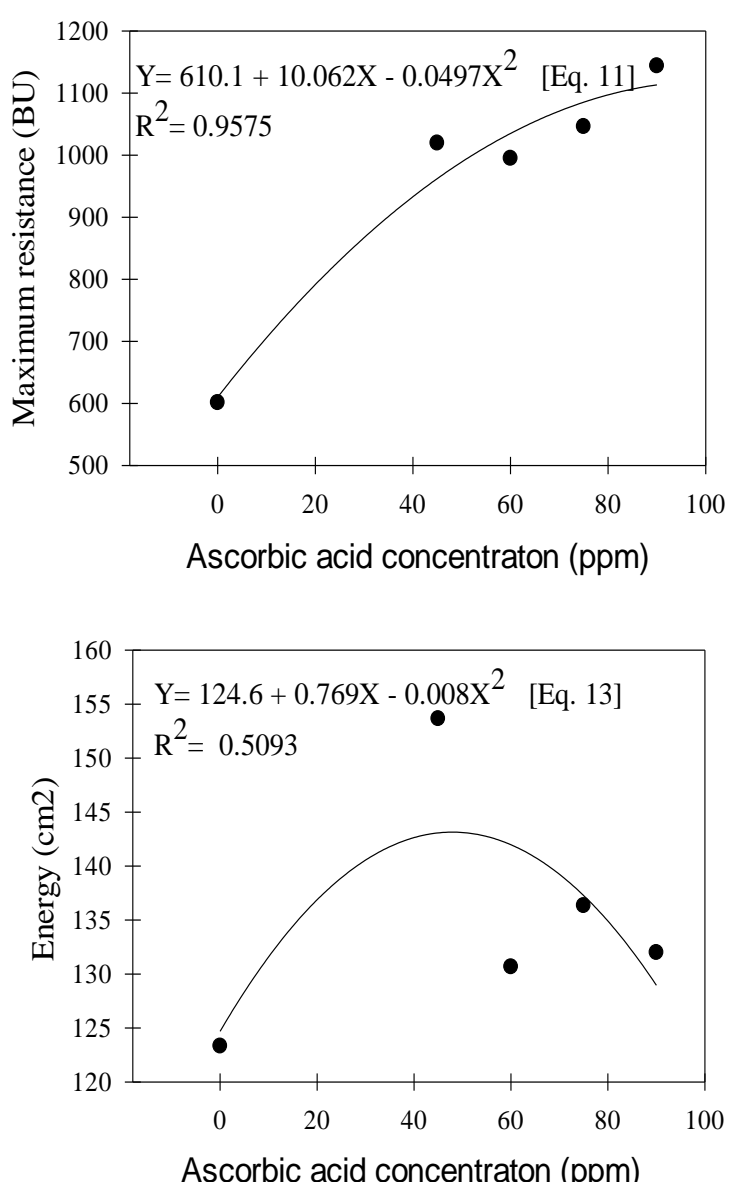

Ascorbic acid concentraton (ppm)

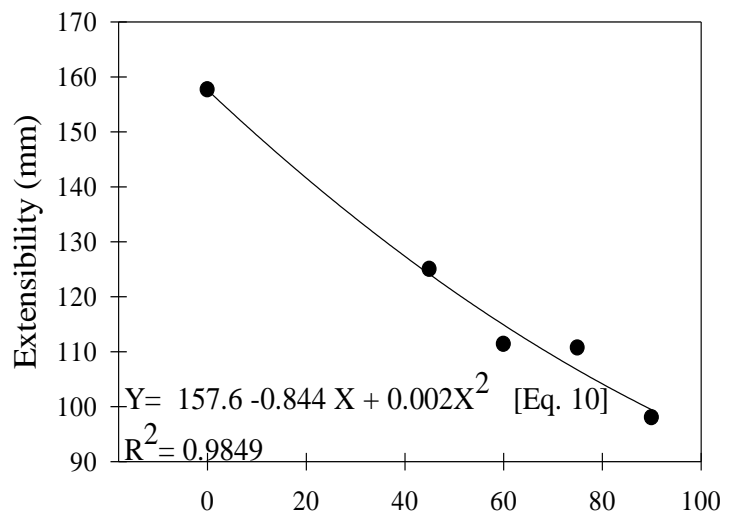

Ascorbic acid concentraton (ppm)
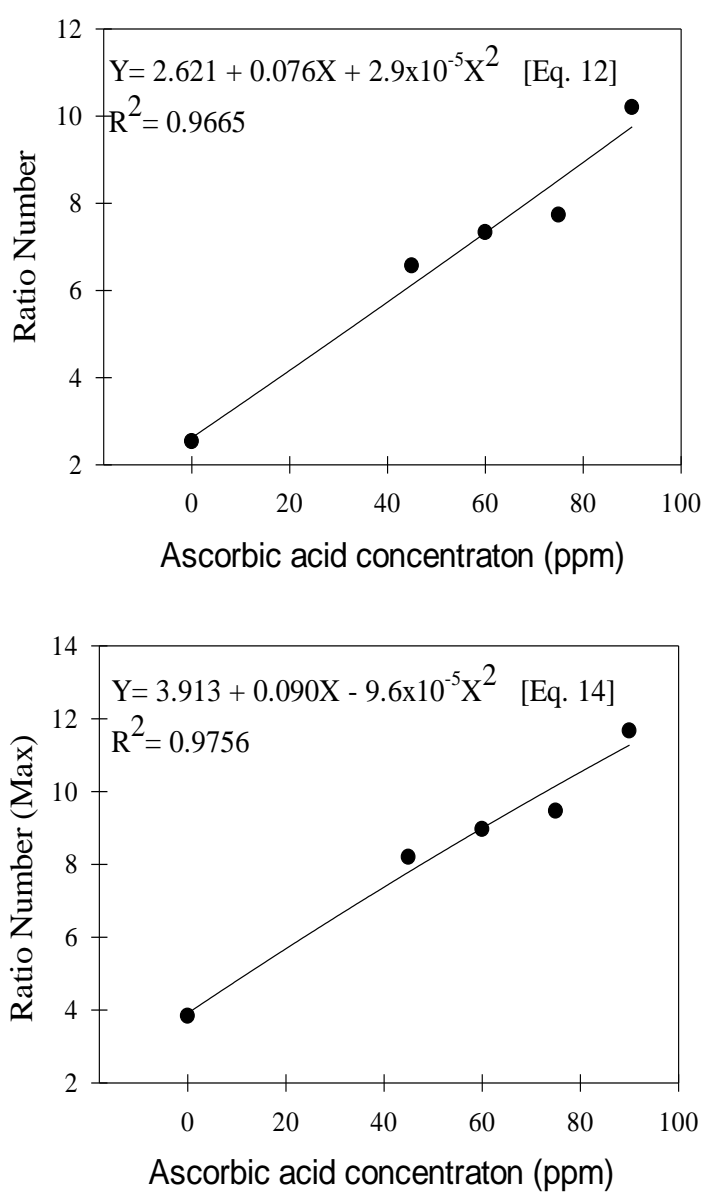

Fig. 2. Polynomial Quadratic trend of ascorbic acid concentration (ppm) versus the extensogram parameters at zero level of $\alpha$ - amylase. 
Three dimension response surface of $\alpha-$ amylase enzyme and ascorbic acid combination on the extensograph parameters

The previous polynomial quadratic regression for each independent variable ( $\alpha$-amylase enzyme or ascorbic acid concentrations) showed low effect of $\alpha$-amylase enzyme and high effect of ascorbic acid on the extensograph parameters as dependent variable. Therefore, the three dimension response surface study was necessary to optimize the combined concentrations from $\alpha$-amylase enzyme and ascorbic acid. The influence of additives (enzymes and ascorbic acid) on wheat flour properties has not been studied; Paucean et al (2016). The plot in Fig. 3 shows the response surface of extensograph parameters as observed in the presence of $\alpha$-amylase enzyme and ascorbic acid at different concentrations.

The predicted model (Eq. 15) had a high determination coefficient $\left(r^{2}=0.9558\right)$. From output data, it could be noticed that the best predicted resistance for that equation was $861 \mathrm{BU}$.

$Y=341.1+31.017 X+27.895 Z-1.3971 X^{2}-0.6285 Z^{2}-$ $0.0204 X^{3}+0.0063 Z^{3}+0.0019 X^{4}-2.1 \times 10^{-5} Z^{4}-$ $0.0013 X^{2} Z^{2}+2.1 \times 10^{-6} X^{3} Z^{3}-9.4 \times 10^{-10} X^{4} Z^{4}$

[Eq. 15]

The response surface showed high correlation $(P \leq 0.05)$ between the $\alpha$-amylase-ascorbic acid combination and maximum resistance. The same trend observed like in the response surface was obtained from resistance data. Predicted model (Eq. 16) fit the relationship of $\alpha$-amylase-ascorbic acid concentrations versus maximum resistance with $r^{2}=0.9273$. The optimum maximum resistance was $1058 \mathrm{BU}$.

$Y=557.4+24.720 X+30.904 Z-0.6657 X^{2}-0.7839 Z^{2}-$ $0.0107 X^{3}+0.0085 Z^{3}-8.2 \times 10^{-5} X^{4}-3.1 \times 10^{-5} Z^{4}-$ $0.0014 X^{2} Z^{2}+2.1 \times 10^{-6} X^{3} Z^{3}-9.3 \times 10^{-10} X^{4} Z^{4}$

[Eq. 16]

According to the response surface, the ascorbic acid had higher effect on the dough extensibility than $\alpha$-amylase. The optimum extensibility was $118 \mathrm{~mm}$ predicted from the model (Eq. 17) as follows:

$Y=165.2-1.2746 X-3.3937 Z-0.0090 X^{2}+0.0983 Z^{2}-$ $0.0010 X^{3}-0.0012 Z^{3}+6.6 \times 10^{-5} X^{4}+5.3 \times 10^{-6} Z^{4}+8.5 \times 10$ ${ }^{5} X^{2} Z^{2}-1.1 \times 10^{-7} X^{3} Z^{3}+4.9 \times 10^{-11} X^{4} Z^{4}$

[Eq. 17]
The ratio number ranged between 1.6 and 10.2 at 0.0 and $0.0 ; 1.8$ and 90 ppm from $\alpha$-amylase and ascorbic acid, respectively. The previous observation was obtained from the output data from the predictive model (Eq. 18). According to that output data it could be concluded that the optimum ratio number for pan bread preparation was 7.8 .

$Y=1.669+0.4076 X+0.3888 Z-0.0229 X^{2}-0.0107 Z^{2}-$ $0.0002 X^{3}+0.0001 Z^{3}+3.9 \times 10^{-5} X^{4}-4.9 \times 10^{-7} Z^{4}-1.5 \times 10$ ${ }^{5} X^{2} Z^{2}+2.5 \times 10^{-8} X^{3} Z^{3}-1.1 \times 10^{-11} X^{4} Z^{4}$

[Eq. 18]

At the same time the maximum ratio number gave the same trend that was obtained from three dimension response surface plot of ratio number. The maximum ratio number ranged between 3.0 and 11.8 at the same $\alpha$-amylase and ascorbic acid concentrations those predicted in the ratio number regression. The suitable predicted maximum ratio number was 9.5. Equation 19 was used to plot the maximum ratio number data as dependent variable agents $\alpha$-amylase and ascorbic acid concentrations as independent variables with $r^{2}=0.9403$ as follows:

$Y=3.010+0.3557 X+0.4632 Z-0.0157 X^{2}-0.0136 Z^{2}-$ $0.0001 X^{3}+0.0002 Z^{3}+1.8 \times 10^{-5} X^{4}-6.6 \times 10^{-7} Z^{4}-1.6 \times 10^{-}$ ${ }^{5} X^{2} Z^{2}+2.6 \times 10^{-8} X^{3} Z^{3}-1.2 \times 10^{-11} X^{4} Z^{4}$

[Eq. 19]

The best energy value for that combination between $\alpha$-amylase and ascorbic acid at different concentrations was $145 \mathrm{~cm}^{2}$. The quaternary model (Eq. 20) showed the best between a-amylase and ascorbic acid concentrations to obtain the high quality dough with $r^{2}=0.6751$ as follows:

$Y=125.3+1.3521 X+0.8428 Z-0.0373 X^{2}-0.0095 Z^{2}-$ $0.0010 X^{3}-5.4 \times 10^{-5} Z^{3}-0.00033 X^{4}+7.6 \times 10^{-7} Z^{4}-$ $0.0001 X^{2} Z^{2}+2.2 \times 10^{-7} X^{3} Z^{3}-8.8 \times 10^{-11} X^{4} Z^{4}$

[Eq. 20]

Fig. (3) helped to obtain the optimum $\alpha$ amylase and ascorbic acid concentrations with extensograph parameter values. These data were extracted from the study of the response surface by plot the $\alpha$-amylase and ascorbic acid concentrations agent's extensograph parameter values. It can be seen that the optimum $\alpha$-amylase and ascorbic acid concentrations (3.8 and 33.8 ppm, respectively). These concentrations can be used to prepare weak flour dough suitable for pan bread making compared to the strong flour. 

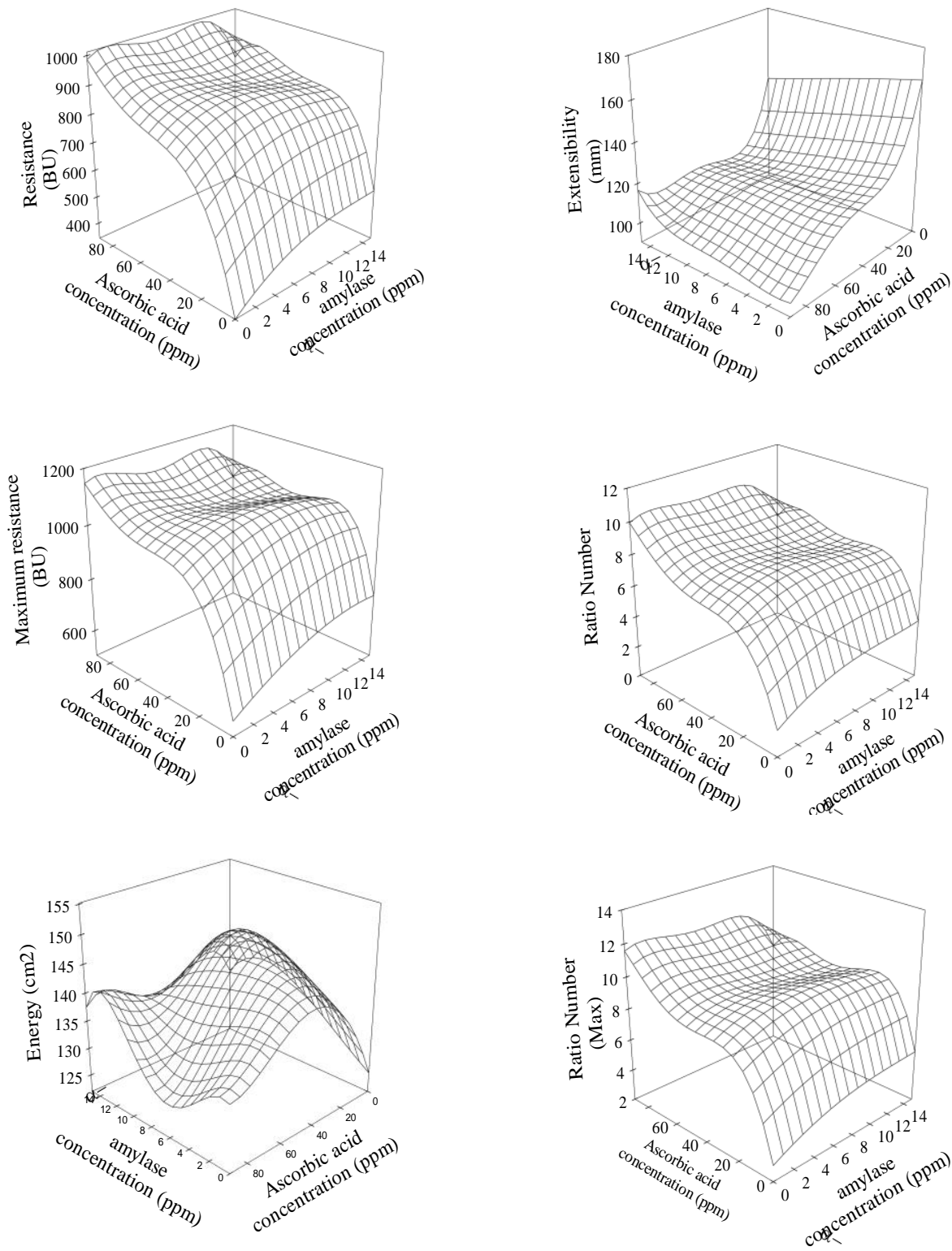

Fig. 3. Three dimension regression plot to predict the extensogram parameters against different $\alpha$-amylase and ascorbic acid concentrations

\section{Verification of predictive extensograph parame-} ter

The verification of the predicted extensograph parameters compared to the same parameters of strong and weak flour presents in Table (2). The optimal extensograph parameters were selected at predicted $\alpha$-amylase and ascorbic acid concentrations 3.8 and 33.8 ppm, respectively. According to the practical experiments, the extensograph parameters of weak flour were not suitable for prepar- ing pan bread dough. Treating the weak flour with 3.8 ppm a-amylase and 33.8 ppm ascorbic acid improved the extensograph parameters. The predictive values were matched with the obtained practical values as Table (2) cleared. According to the strong flour extensograph parameter values, it could be noticed that the three dimension response surface models gave right predictive values. At the same time, it can use the a-amylase and ascorbic acid with weak flour to improve the extensograph dough characteristics. 
Table 2. Effect of matrix of ascorbic acid and fungal $\alpha$ amylase on Extensogram at $90 \mathrm{~min}$

\begin{tabular}{|c|c|c|c|c|c|}
\hline \multicolumn{2}{|c|}{ Level of addition } & \multicolumn{4}{|c|}{ Extensograph parameters } \\
\hline a. Amylase & $\begin{array}{c}\text { Ascorbic } \\
\text { acid }\end{array}$ & Energy & Max. resistance & Extensibility & Ratio no. (max) \\
\hline \multirow[t]{5}{*}{0} & 0 & $123.3^{b}$ & $601.3^{g}$ & $157.7^{a}$ & $3.8^{h}$ \\
\hline & 45 & $153.7^{\mathrm{a}}$ & $1019.7^{\text {cde }}$ & $125^{b c}$ & $8.2^{\text {ef }}$ \\
\hline & 60 & $130^{\mathrm{ab}}$ & $995^{\text {de }}$ & $111.3^{\text {cdef }}$ & $9^{\text {def }}$ \\
\hline & 75 & $136.3^{\mathrm{ab}}$ & $1046.3^{\text {abcde }}$ & $110.7^{\text {cdef }}$ & $9.5^{\text {bcde }}$ \\
\hline & 90 & $132^{a b}$ & $1144^{\mathrm{a}}$ & $98^{f}$ & $11.7^{\mathrm{a}}$ \\
\hline \multirow[t]{5}{*}{5} & 0 & $130^{\mathrm{b}}$ & $611.7^{\mathrm{g}}$ & $165.3^{a}$ & $3.7^{\mathrm{h}}$ \\
\hline & 45 & $142.3^{a b}$ & $1070.3^{\text {abcde }}$ & $114.3^{\text {cde }}$ & $9.4^{\text {bcdef }}$ \\
\hline & 60 & $143.7^{a b}$ & $1085.3^{\mathrm{abcd}}$ & $111.7^{\text {cdef }}$ & $9.7^{\mathrm{bcd}}$ \\
\hline & 75 & $131.7^{\mathrm{ab}}$ & $1069.7^{\text {abcde }}$ & $104.3^{\text {def }}$ & $10.4^{\mathrm{abc}}$ \\
\hline & 90 & $129^{b}$ & $1133.3^{\mathrm{ab}}$ & $97.7^{f}$ & $11.6^{\mathrm{a}}$ \\
\hline \multirow[t]{5}{*}{10} & 0 & $143^{a b}$ & $688^{g}$ & $159^{a}$ & $4.3^{h}$ \\
\hline & 45 & $130^{b}$ & $1073^{\text {abcd }}$ & $103.7^{\text {ef }}$ & $10.4^{\mathrm{abc}}$ \\
\hline & 60 & $143^{a b}$ & $1054.7^{\text {abcde }}$ & $115^{\text {cde }}$ & $9.2^{\text {cdef }}$ \\
\hline & 75 & $134.7^{a b}$ & $1033.3^{\text {bcde }}$ & $112.3^{\text {cdef }}$ & $9.2^{\text {cdef }}$ \\
\hline & 90 & $134.7^{a b}$ & $1147^{\mathrm{a}}$ & $99^{f}$ & $11.6^{\mathrm{a}}$ \\
\hline \multirow[t]{5}{*}{15} & 0 & $134^{\mathrm{ab}}$ & $784^{f}$ & $137^{b}$ & $5.8^{g}$ \\
\hline & 45 & $137.3^{a b}$ & $968.3^{e}$ & $120.3^{c}$ & $8.1^{f}$ \\
\hline & 60 & $134^{\mathrm{ab}}$ & $989.3^{\mathrm{de}}$ & $117^{\text {cde }}$ & $8.5^{\text {def }}$ \\
\hline & 75 & $137.7^{a b}$ & $1102.3^{a b c}$ & $103.7^{\text {ef }}$ & $10.6^{\mathrm{ab}}$ \\
\hline & 90 & $138^{a b}$ & $983^{\text {de }}$ & $119^{c d}$ & $8.3^{\text {ef }}$ \\
\hline
\end{tabular}

Means in the same column with different letters are significantly different $(P \leq 0.05)$

\section{Texture profile analysis of pan bread}

Effect of predicted $\alpha$-amylase and ascorbic acid concentrations (3.8 and $33.8 \mathrm{ppm}$ ) used with weak flour dough on the texture profile of pan bread during storage period $\left(25 \pm 2^{\circ} \mathrm{C} / 72 \mathrm{~h}\right)$ is presented in Table 3. Texture is an important characteristic in consumer's perception of food and influences the purchasing decisions (Meilgaard et al 1991). The Texture profile analysis results, obtained by means of double cycle compressions evidenced the structural changes that affected the samples during storage and clearly differentiated control from the various enzyme-added samples (Raffo et al 2003).

The texture profile of treated pan bread with fungal $\alpha$-amylase and ascorbic acid compared with the texture profile of pan bread prepared by weak and strong flour as a negative and positive control are noticed in Table 3 . The hardness, chewiness and gumminess were significantly $(P \leq 0.05)$ affected by the added $\alpha$-amylase and ascorbic acid. The prepared sample by weak flour significantly $(P \leq 0.05)$ had the highest hardness, chewiness and gumminess values at zero time compared to the samples prepared by treated samples with fungal a-amylase and ascorbic acid and strong flour.

Table 3. Optimum rheological predictive values at 3.8 ppm. $\alpha$-amylase and 33.8 ppm. Ascorbic acid as predictive concentrations.

\begin{tabular}{|l|c|c|c|c|}
\hline Parameters & $\begin{array}{c}\text { Pre- } \\
\text { dictive } \\
\text { values }\end{array}$ & $\begin{array}{c}\text { Veri- } \\
\text { fied } \\
\text { values }\end{array}$ & $\begin{array}{c}\text { Strong } \\
\text { flour } \\
\text { Positive } \\
\text { control }\end{array}$ & $\begin{array}{c}\text { Weak } \\
\text { flour } \\
\text { Nega- } \\
\text { tive } \\
\text { con- } \\
\text { trol }\end{array}$ \\
\hline Resistance (BU) & 861 & 856 & 876 & 397 \\
Extensibility (mm) & 118 & 105 & 122 & 156 \\
Maximum resistance & 1058 & 1042 & 986 & 591 \\
(BU) & 7.8 & 8.2 & 7.2 & 2.5 \\
Ratio number & 9.5 & 10 & 8.1 & 3.8 \\
Ratio number (Max) & 145 & 133 & 140 & 122 \\
\hline Energy (cm ${ }^{2}$ ) & & & \\
\hline
\end{tabular}

$\mathrm{BU}=$ Brabender unit 
Table 4. Texture profile analysis of pan bread prepared using predicted optimum $\alpha$-amylase and ascorbic acid concentrations during $72 \mathrm{~h}$ storage period at room temperature $25 \pm 2{ }^{\circ} \mathrm{C}$

\begin{tabular}{|c|c|c|c|c|c|c|c|c|}
\hline 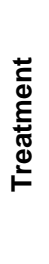 & $\stackrel{\text { g) }}{=}$ & 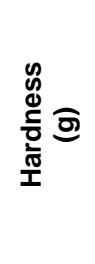 & 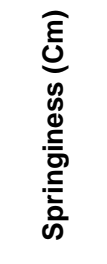 & 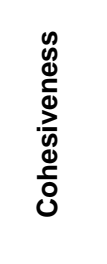 & 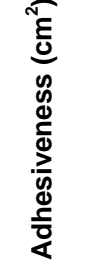 & 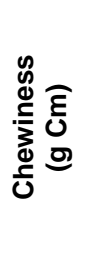 & 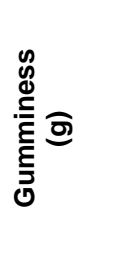 & 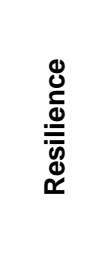 \\
\hline $\mathbf{W}$ & & $397^{c}$ & $0.88^{\mathrm{abc}}$ & $0.74^{\mathrm{ab}}$ & $1.18^{\mathrm{a}}$ & $258^{a}$ & $290.1^{a}$ & $0.43^{\mathrm{ab}}$ \\
\hline $\mathbf{T}$ & zero & $57^{d}$ & $0.81^{\mathrm{e}}$ & $0.73^{\mathrm{ab}}$ & $0.01^{b}$ & $34^{c}$ & $42^{c}$ & $0.36^{\mathrm{cd}}$ \\
\hline $\mathbf{S}$ & & $88^{\mathrm{de}}$ & $0.9^{a}$ & $0.77^{\mathrm{a}}$ & $0.00^{b}$ & $61^{b c}$ & $68^{b c}$ & $0.46^{a}$ \\
\hline W & & $584^{\mathrm{b}}$ & $0.85^{\mathrm{cd}}$ & $0.58^{\mathrm{e}}$ & $0.00^{b}$ & $288^{a}$ & $336^{a}$ & $0.27^{e}$ \\
\hline $\mathbf{T}$ & $24 \mathrm{~h}$ & $89^{\mathrm{de}}$ & $0.85^{\mathrm{cd}}$ & $0.70^{\mathrm{bc}}$ & $0.03^{b}$ & $53^{\mathrm{bc}}$ & $62^{\mathrm{bc}}$ & $0.33^{\text {cde }}$ \\
\hline $\mathrm{S}$ & & $142^{\text {de }}$ & $0.9^{\mathrm{a}}$ & $0.70^{b c}$ & $0.01^{b}$ & $88^{b}$ & $99^{b}$ & $0.38^{b c}$ \\
\hline W & & $688^{a}$ & $0.83^{\mathrm{de}}$ & $0.48^{f}$ & $0.26^{b}$ & $273^{a}$ & $330^{\mathrm{a}}$ & $0.2^{f}$ \\
\hline $\mathbf{T}$ & $48 \mathrm{~h}$ & $93^{\mathrm{de}}$ & $0.87^{b c}$ & $0.71^{\mathrm{ab}}$ & $0.00^{b}$ & $57^{\mathrm{bc}}$ & $66^{\mathrm{bc}}$ & $0.35^{\mathrm{cd}}$ \\
\hline $\mathrm{S}$ & & $174^{d}$ & $0.89^{a b}$ & $0.62^{\mathrm{de}}$ & $0.01^{b}$ & $95^{b}$ & $107^{\mathrm{b}}$ & $0.32^{\text {cde }}$ \\
\hline $\mathbf{W}$ & & $748^{a}$ & $0.78^{f}$ & $0.45^{f}$ & $0.09^{b}$ & $261^{a}$ & $337^{\mathrm{a}}$ & $0.18^{f}$ \\
\hline $\mathbf{T}$ & $72 \mathrm{~h}$ & $153^{\mathrm{de}}$ & $0.87^{b c}$ & $0.64^{\mathrm{cd}}$ & $0.00^{b}$ & $85^{b c}$ & $98^{b}$ & $0.35^{\mathrm{cd}}$ \\
\hline $\mathrm{S}$ & & $179^{d}$ & $0.89^{\mathrm{ab}}$ & $0.58^{\mathrm{e}}$ & $0.00^{b}$ & $84^{b c}$ & $102^{b}$ & $0.3^{\mathrm{de}}$ \\
\hline
\end{tabular}

Means in the same column with different letters are significantly different $(P \leq 0.05)$

$\mathrm{W}=$ weak flour; $\mathrm{S}=$ strong flour; $\mathrm{T}=$ treated flour by $\alpha$-amylase and ascorbic acid at concentrations 3.8 and $33.8 \mathrm{ppm}$, respectively

The increased gumminess of a-amylase treated bread is associated with the production of branched maltodextrins of DP20-100 (DeStefanis and Turner, 1981). Which is the compound responsible for the gumminess associated with $\alpha$ amylase treated bakery products (Van der Maarel et al 2002). Non-significant $(P \geq 0.05)$ was observed between the pan bread samples prepared using the treated flour with fungal $\alpha$-amylase and ascorbic acid and strong flour. $\alpha$-amylases supply the bread dough by dextrins with degree of polymerization 3-9 which are intermediate products in the conversion of starch to maltose. These low molecular weight dextrins are effective in decreasing bread hardness (Ziobro et al 1998 and Defloor \& Delcour 1999). With increasing the storage period the hardness, chewiness and gumminess values gradually increased. The maximum values were observed at the end of storage period after $72 \mathrm{~h}$. The weak flour pan bread sample had the highest hardness, chewiness and gumminess values were $748 \mathrm{~g}, 261 \mathrm{~g} . \mathrm{cm}$ and $337 \mathrm{~g}$. At the same time no significant differences $(P \leq 0.05)$ were observed between the samples prepared from treated flour with fungal a-amylase and ascorbic acid and strong flour after $72 \mathrm{~h}$. The products of starch depolymerisation produced by $\alpha$-amylase have antifirming properties, Leon et al (1981), caused by the interactions of low molecular weight dextrins with starch and gluten (Martin and Hoseney 1991). Staling of bread prepared from dough supplemented with a-amylase occurred at a slower rate than without supplementation, Hopek et al (2006).

On the other hand, Springiness, cohesiveness, adhesiveness and resilience fallen as a result to storage during $72 \mathrm{~h}$. At the beginning of storage period the differences between the three prepared samples in the springiness, cohesiveness, adhesiveness and resilience were significantly negligible. With increasing the storage period, the springiness, cohesiveness, adhesiveness and resilience values decreased. At the end of storage period non-significant differences $(P \geq 0.05)$ were observed between the samples prepared from treated flour with fungal $\alpha$-amylase and ascorbic acid and strong flour compared to the sample prepared from weak or non-treated flour. Both of adhesiveness and resilience of the samples prepared from treated flour with fungal $\alpha$-amylase and ascorbic acid and strong flour had values without significant differences compared with those values at zero time. During the whole storage period considered, the enzyme-containing breads were markedly softer than control and, compared to it, only a slight increase of hardness was observed, demonstrating 
the anti-staling effectiveness of the enzyme, Giannone et al (2016).

Generally, used $\alpha$-amylase and ascorbic acid at predicted concentrations with weak flour enhance the texture profile for the prepared pan bread. Nonsignificant differences $(P>0.05)$ were observed in the obtained texture profile parameters of pan bread prepared from treated weak flour with fungal $\alpha$-amylase and ascorbic acid compared to the parameters were obtained from pan bread prepared from strong flour. The addition of fungal $\alpha$-amylase made the good dough structure, Kim et al (2006) and increased mean cell area and decreased crumb elasticity. A more open gluten network formed by fibrous elements has been suggested by Blaszczak et al (2004) as the responsible for the higher elasticity and lower hardness of the crumb after treatments with $\alpha$-amylase, Caballero et al (2007).

\section{Color parameters of pan bread}

The crumb brightness $\left(L^{*}\right)$ values of the pan bread samples prepared using optimum a-amylase and ascorbic acid concentrations (3.8 and 33.8 ppm) and strong flour were significantly $(P \leq 0.05)$ lower than the sample that prepared using weak flour. The brightness values in all prepared samples negligible increased after storage period for $72 \mathrm{~h}$ (Table, 5) with non-significant differences $(P \geq 0.05)$ compared to those values obtained at zero time. The same trend was observed after 72 h. On the other hand, the redness $\left(\mathrm{a}^{*}\right)$ and yellowness $\left(b^{*}\right)$ values were significantly $(P \leq 0.05)$ higher in prepared pan bread sample from weak flour. Non-significant $(P \geq 0.05)$ difference was observed in the pan bread samples prepared using treated samples with fungal $\alpha$-amylase and ascorbic acid and strong flour at zero time. After $72 \mathrm{~h}$ the pan bread samples had the same redness and yellowness means with non-significant differences $(P \geq 0.05)$. Treated bread using $\alpha$-amylase and ascorbic acid gave uniform pores compared with control which reflect a bright crumb (Hopek et al 2006).

\section{Specific volume and sensory evaluation}

The improved bread volume was caused by the increased amount of fermentable sugars those generated by enzyme treatment. The content of mono- and oligosaccharides in wheat flour is quite small, generally not exceeding $0.5 \%$. This amount is not sufficient to obtain the fermentation require- ments to give good loaf volume; consequently bread quality depends on the generation of maltose by the $\alpha$ - and $\beta$-amylase of the flour. Usually wheat flour contains a sufficient amount of $\beta$ amylase (Jankowski 1969 and Ambroziak 1992). However, only a-amylase is able to hydrolyze native undamaged starch although the degradation rate is low and depend on dosage of enzyme, Jankowski (1969). According to Fig. 4 A, the treated pan bread had slightly low specific volume value compared to strong flour pan bread. The weak flour pan bread had the lowest specific volume compared to other two prepared samples with fungal $\alpha$-amylase with ascorbic acid and strong flour. Fungal $\alpha$-amylase had a positive impact on bread volume which depended on the dosage of enzyme (Hopek et al 2006). Dough Loaf volume increased with added ascorbic acid. Ascorbic acid strengthens the gluten matrix by increasing the density of di-sulphide bonds in gluten. Stronger gluten leads to higher loaf volumes as a result of high gas retention capacity compared with untreated bread (Aamodt et al 2003 and Koehler, 2003). Pan bread prepared using weak flour with 3.8 and 33.8 ppm a-amylase and ascorbic acid had higher crust, crumb color, uniformity of pore size and overall acceptability scores with significant differences $(P \leq 0.05)$ compared to the pan bread sample prepared using weak flour without added $\alpha$ amylase and ascorbic acid (negative control).

Table 5. Color of crumb and crust for pan bread prepared using predicted optimum a-amylase and ascorbic acid concentrations during $72 \mathrm{~h}$ storage period at room temperature $25 \pm 2^{\circ} \mathrm{C}$.

\begin{tabular}{|c|c|c|c|c|c|}
\hline Treatment & time & $\mathrm{L}^{*}$ & $\mathrm{a}^{*}$ & $\mathrm{~b}^{*}$ & $\Delta \mathrm{E}$ \\
\hline $\mathrm{W}$ & & $70.8^{\mathrm{cd}}$ & $-0.3^{\mathrm{a}}$ & $16.3^{\mathrm{ab}}$ & $48.7^{\mathrm{cd}}$ \\
$\mathrm{S}$ & \multirow{2}{*}{ zero } & $78.2^{\mathrm{a}}$ & $-1.1^{\mathrm{cd}}$ & $15.8^{\mathrm{bcd}}$ & $55.5^{\mathrm{ab}}$ \\
$\mathrm{T}$ & & $78.2^{\mathrm{a}}$ & $-1.0^{\mathrm{c}}$ & $15.3^{\mathrm{def}}$ & $55.4^{\mathrm{ab}}$ \\
$\mathrm{W}$ & & $70.1^{\mathrm{d}}$ & $-0.4^{\mathrm{ab}}$ & $16.2^{\mathrm{ab}}$ & $48^{\mathrm{d}}$ \\
$\mathrm{S}$ & \multirow{2}{*}{$24 \mathrm{~h}$} & $74.1^{\mathrm{bc}}$ & $-1.1^{\mathrm{cd}}$ & $15.1^{\mathrm{ef}}$ & $51.5^{\mathrm{cd}}$ \\
$\mathrm{T}$ & & $78.4^{\mathrm{a}}$ & $-1.1^{\mathrm{cd}}$ & $15.1^{\mathrm{ef}}$ & $55.6^{\mathrm{ab}}$ \\
$\mathrm{W}$ & & $70.8^{\mathrm{cd}}$ & $-0.6^{\mathrm{b}}$ & $16.1^{\mathrm{abc}}$ & $48.6^{\mathrm{cd}}$ \\
$\mathrm{S}$ & \multirow{4}{*}{$48 \mathrm{~h}$} & $74.7^{\mathrm{b}}$ & $-1.2^{\mathrm{d}}$ & $15.0^{\mathrm{f}}$ & $52^{\mathrm{bc}}$ \\
$\mathrm{T}$ & & $78.3^{\mathrm{a}}$ & $-1.2^{\mathrm{d}}$ & $15.1^{\mathrm{ef}}$ & $55.5^{\mathrm{ab}}$ \\
$\mathrm{W}$ & & $72.9^{\mathrm{bcd}}$ & $-0.5^{\mathrm{b}}$ & $16.5^{\mathrm{a}}$ & $50.7^{\mathrm{cd}}$ \\
$\mathrm{S}$ & $72 \mathrm{~h}$ & $78.2^{\mathrm{a}}$ & $-1.3^{\mathrm{d}}$ & $15.7^{\mathrm{bcde}}$ & $55.6^{\mathrm{ab}}$ \\
$\mathrm{T}$ & & $80.1^{\mathrm{a}}$ & $-1.3^{\mathrm{d}}$ & $15.4^{\mathrm{cdef}}$ & $58.3^{\mathrm{a}}$ \\
\hline
\end{tabular}

Means in the same column with different letters are significantly different $(P \leq 0.05)$.

$\mathrm{W}=$ weak flour; $\mathrm{S}=$ strong flour; $\mathrm{T}=$ treated flour by $\alpha$ amylase and ascorbic acid at concentrations 3.8 and 33.8 ppm, respectively 

flour dough and sensory properties of pan bread
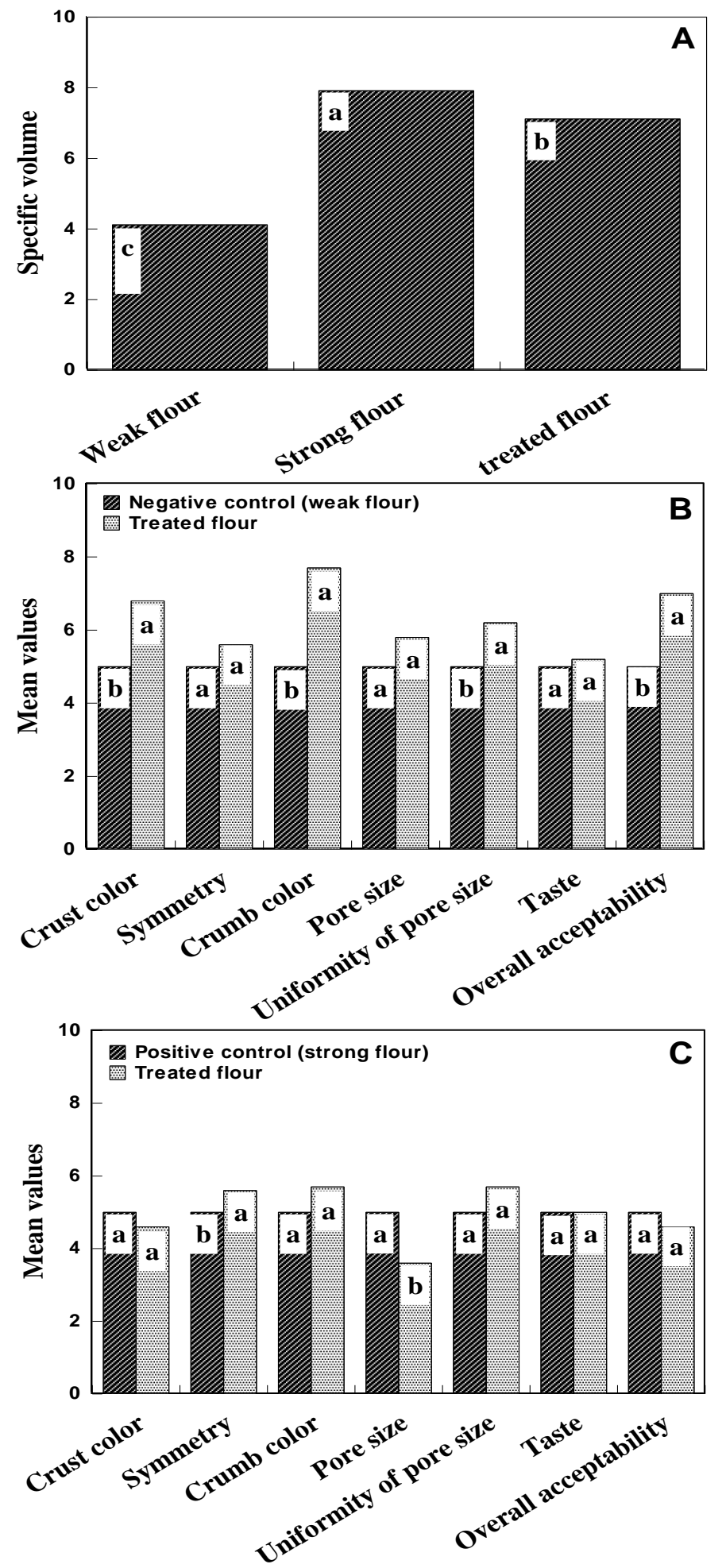

Fig. 4. Specific volume (A) and sensory evaluation of pan bread prepared using optimum $\alpha$-amylase and ascorbic acid concentrations compared to pan Bread prepared from weak and strong flour as negative (B) and positive $(\mathrm{C})$ control 

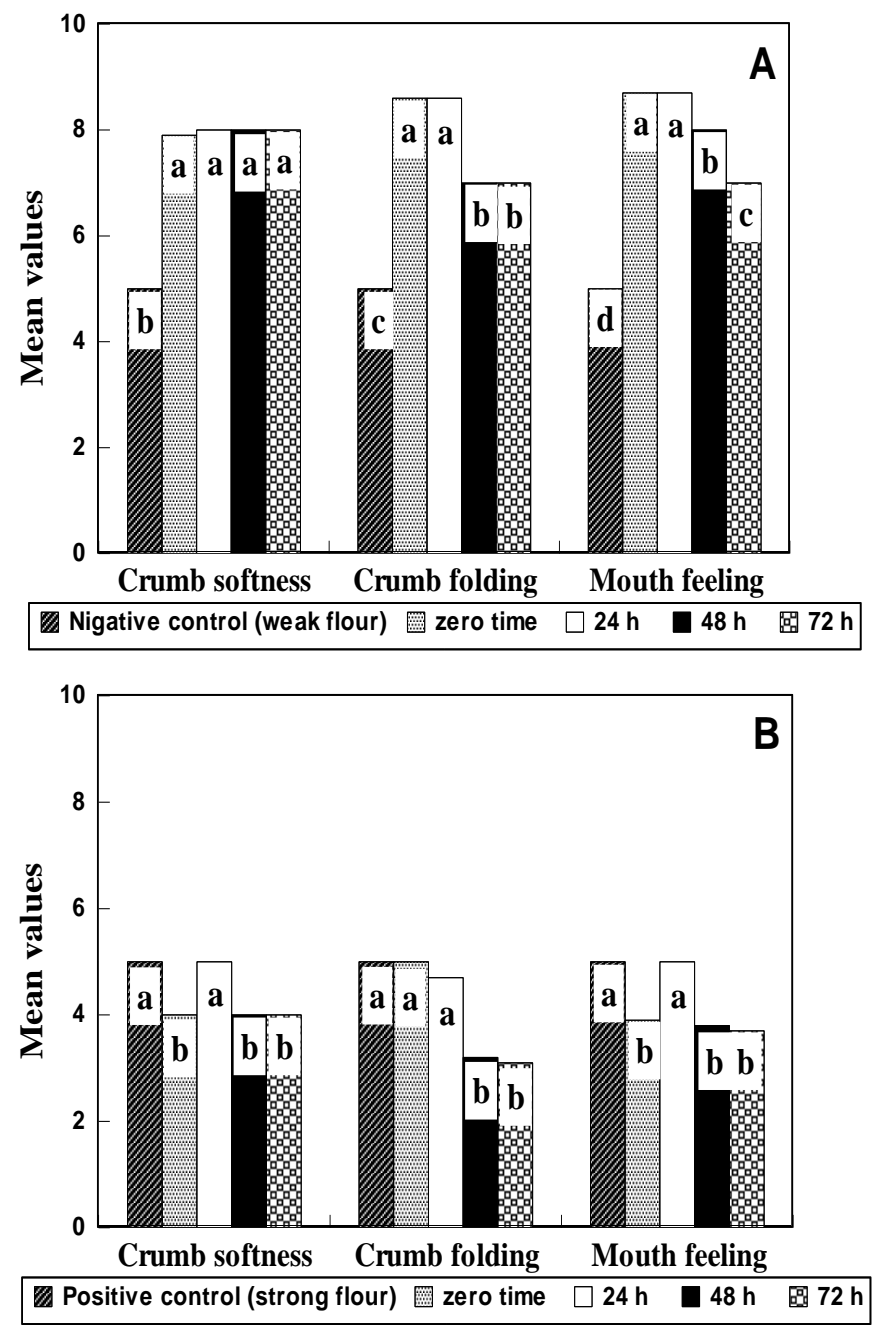

Fig.5. Staling characteristics of pan bread prepared using optimum $\alpha$-amylase and ascorbic acid concentrations compared to pan bread prepared from weak and strong flours as negative (A) and positive (B) controls.

At the same time, non-significant differences $(P \geq 0.05)$ were observed in the crust color, pore size and taste between the treated and untreated samples Fig. 4 B. On the other hand, the treated pan bread had non-significant differences $(P \geq 0.05)$ in crust color, crumb color, uniformity of pore size, taste and overall acceptability compared to the sample prepared using strong flour as positive control Fig. 4 C. The treated pan brad had higher symmetry mean value than the positive control. On the contrary, the pore size mean value in positive control was higher than in treated pan bread sample. Increased levels of reducing sugars promote the generation of Maillard reaction products, which intensify bread flavor and crust color (Drapron \& Godon, 1987 and Bowles, 1996). Ascorbic acid also improves crust characteristics, crumb structure and color (Yamada and Preston, 1994).

\section{Staling characteristics}

Stalling characteristics during $72 \mathrm{~h}$ of pan bread prepared using optimum $\alpha$-amylase and ascorbic acid concentrations compared to pan bread prepared from weak and strong flour as a negative and positive control respectively are presented in Fig. 5. According to the hedonic scale, the control samples had means values 5 . The pan bread sample that prepared using treated weak flour had significant $(P \leq 0.05)$ crumb softness with high mean values compared to the negative control at all storage periods. The crumb folding and 

flour dough and sensory properties of pan bread

mouth feeling values were higher in treated pan bread than negative control with mean values ranged between 8.6 and 8.7. Bread prepared without enzyme showed a more opened structure, and a dry and opaque crumb, with rigid and fragile features typical of retrograded starch (Giannone et al 2016). But, after $48 \mathrm{~h}$ from storage the two attributes (crumb folding and mouth feeling) significantly $(P \leq 0.05)$ decreased with higher values compared to the control. On the other hand, the crumb softness was significantly lower in treated pan bread than the positive control at zero time. Then improvement was observed after $24 \mathrm{~h}$ with nonsignificant difference $(P \geq 0.05)$ compared to the positive control, Fig. 5 B. The same trend was observed with the crumb folding and mouth feeling. Non-significant differences were observed between treated pan bread and positive control after $24 \mathrm{~h}$. But, after $24 \mathrm{~h}$ each of crumb folding and mouth feeling significantly decreased to the minimum values after $72 \mathrm{~h}$ which being 3.1 and 3.7, respectively. Amylase reduces the connectivity between the crystallites in the continuous starch phase and limits the size of the crystals by hydrolyzing branched chains into smaller entities and thus contributing to soft texture (Boyle and Hebeda, 1990 and Hug-Iten et al 2003).

Generally it could be noticed that, the treated pan bread (high freshness) had lower significant staling characteristics values than other pan bread samples prepared from weak flour. On the contrary, the staling characteristics values were relatively high (low freshness) in treated pan bread compared to that prepared from strong flour. That means there should be add staling improver to enhance the staling characteristics of pan bread prepared from weak flour.

\section{CONCLUSION}

Optimum a-amylase and ascorbic acid concentrations were obtained to prepare pan bread using weak flour. Fungal $\alpha$-amylase concentration had a significant $(P \leq 0.05)$ effect on the extensograph parameters. Ascorbic acid enhanced the extensograph parameters compared to the a-amylase enzyme. Both of resistance and maximum resistance were increased with increasing the ascorbic acid concentration from 0.0 to $60 \mathrm{ppm}$ with higher increasing rates than were observed with using $\alpha$ amylase enzyme.

The optimal extensograph parameters were selected at predicted $\alpha$-amylase and ascorbic acid concentrations 3.8 and 33.8 ppm, respectively.
Treating the weak flour with $3.8 \mathrm{ppm} \alpha$-amylase and $33.8 \mathrm{ppm}$ ascorbic acid improved the extensograph parameters. It could be noticed that the three dimension response surface models gave right predictive values. At the same time, it can use the a-amylase and ascorbic acid with weak flour to improve the extensograph dough characteristics.

Non-significant differences $(P \geq 0.05)$ were observed in the obtained texture profile parameters of pan bread prepared from treated weak flour with fungal $\alpha$-amylase and ascorbic acid compared to the parameters were obtained from pan bread prepared from strong flour.

Pan bread prepared using weak flour with 3.8 and $33.8 \mathrm{ppm} \alpha$-amylase and ascorbic acid had higher crust, crumb color, uniformity of pore size and overall acceptability scores with significant differences $(P \leq 0.05)$ compared to the pan bread sample prepared using weak flour without added $\alpha$-amylase and ascorbic acid (negative control).

The pan bread sample that was prepared using fungal $\alpha$. amylase and ascorbic acid treated weak flour had significant $(P \leq 0.05)$ crumb softness with high mean values compared to the negative control at all storage periods ( 0 time, 24, 48 and $72 \mathrm{~h}$ ). The crumb folding and mouth feeling values were higher in treated pan bread than negative control with mean values ranged between 8.6 and 8.7. The crumb softness was significant lower in treated pan bread than the positive control at zero time. Non-significant differences were observed between treated pan bread and positive control after $24 \mathrm{~h}$.

Generally it could be noticed that the treated pan bread had significantly lower staling characteristics values (high freshness) than other pan bread samples prepared from weak flour. On the contrary, the staling characteristics values were relatively high (low freshness) in treated pan bread compared to that prepared from strong flour. Therefore, the improvement of staling characteristics in treated pan beard need more studies.

\section{REFERENCES}

A.A.C.C. 2012. International Methods approved of the American Association of Cereal Chemists, $11^{\text {th }}$ Ed., AACC, Inc., St. Paul: Minnesota, USA.

Aamodt, A., Magnus, E.M. and Faergestad, E.M. 2003. Effect of flour quality, ascorbic acid, and DATEM on dough rheological parameters and hearth loaves characteristics. J. Food Sci., Food Chemistry and Toxicology. 68, 22012210. 
Ambroziak Z., 1992. Cited by Hopek M., Ziobro R. and Achremowicz, B. 2006. Comparison of the effects of the microbial $\alpha$-amylase and scalded flour on bread quality. Acta Sci. Pol., Technol. Aliment. 5, 97-106.

Blaszczak, W., Sadowska, J., Rosell, C.M. and Fornal, J. 2004. Structural changes in the wheat dough and bread with the addition of alpha amylases. Euro. Food Research and Technol. 219, 348-354.

Bowles, L.K. 1996. Amylolytic enzymes. In: "Baked goods freshness: Technology, evaluation, and inhibition of staling". Hebeda, R.E. and Zobel H.F. (Eds.). pp. 105-129. NY, Marcel Dekker, New York, U.S.A.

Boyle, P.J. and Hebeda, R.E. 1990. Antistaling enzyme for baked goods. Food Technol. 44(6), 29-129.

Caballero, P.A., Gomez, M. and Rosell, C.M. 2007. Improvement of dough rheology, bread quality and bread shelf-life by enzymes combination. J. Food Engineering. 81, 42-53.

Colakoglu, A.S. and Ozkaya, H. 2012. Potential use of exogenous lipases for DATEM replacement to modify the rheological and thermal properties of wheat flour dough. J. Cereal Sci. $55,397-404$.

Duncan, D.B., 1955. Multiple range and multiple $F$ tests. Biometrics, 11, 1-42.

De-Stefanis, V.A. and Turner, E.W. 1981. Modified enzyme system to inhibit bread firming method for preparing same and use of same in bread and other bakery products. U.S. Patent 4299848.

Defloor, I. and Delcour, J.A. 1999. Impact of maltodextrins and antistaling enzymes on the differential scanning calorimetry staling endotherm of baked doughs. J. Agric. and Food Chem. 47, 731-741.

Drapron, R. and Godon B. 1987. Role of enzymes in baking. In: "Enzymes and their role in cereal technology”. Kruger, J.E., Lineback D. and Stauffer C.E. (Eds.) pp. 281-324. American Association of Cereal Chemists, St. Paul, Minnesota, U.S.A.

Dunnewing, B., van Vliet, T. and Orsel, R. 2002. Cited by Paucean, Adriana; Simona M. Man and Sonia A. Socaci, 2016. Wheat germ bread quality and dough rheology as influenced by added enzymes and ascorbic acid. Studia Universitatis Babes-Bolyai Chemia. 2, 103118.
Giannone, V., Maria, R. Lauro, Spina A., Antonella Pasqualone; Lucrezia Auditore, Ivana Puglisi and Puglisi, G. 2016. A novel a.amylase-lipase formulation as anti-staling agent in durum wheat bread. LWT-Food Sci. and Technol. 65, 381-389.

Gomes-Ruffi, C.R., da Cunha R.H., Eveline L. Almeida; Changand Y.K. CarolineJ. Steel, 2012. Effect of the emulsifier sodium stearoyll actylate and of the enzyme maltogenic amylase on the quality of pan bread during storage. LWT-Food Sci. and Technol. 49, 96-101.

Hopek, M., Ziobro, R. and Achremowicz B., 2006. Comparison of the effects of the microbial $\alpha$-amylase and scalded flour on bread quality. Acta Sci. Pol., Technol. Aliment. 5, 97106.

Hruskova, Marie and Dana Novotna, 2003. Effect of ascorbic acid on the rheological properties of wheat fermented dough. Czech J. Food Sci. 21, 137-144.

Hug-Iten, S., Escher, F. and Conde-Petit, B. 2003. Staling of bread; role of amylose and amylopectin and influence of starch degrading enzymes. Cereal Chem., 80, 654-661.

I.C.C., 2012. Standard Methods of the International Association for Cereal Science and Technology, ICC, Marxergasse 2, Vienna, AT, Austria

Jankowski S., 1969. Cited by Hopek M., Ziobro, R. and Achremowicz B. 2006. Comparison of the effects of the microbial $\alpha$-amylase and scalded flour on bread quality. Acta Sci. Pol., Technol., Aliment. 5, 97-106.

Kaltsa, O., Georgopoulos, T., Yanniotis S. and Mandalal, 2013. Effect of enzyme blends and dough strengthening emulsifier on extending the shelf Life of sandwich bread applying response surface methodology. International J. Engineering and Innovative Technol., 3(4), 149-160.

Kim, J.H., Maeda, T. and Morita, N. 2006. Effect of fungal $\alpha$-amylase on the dough properties and bread quality of wheat flour substituted with polished flours. Food Research International. 39, 117-126.

Koehler, P. 2003. Effect of ascorbic acid in dough: reaction of oxidized glutathione with reactive thiol groups of wheat glutelin. J. Agric. Food Chem. 51, 4954-4959.

Larmond, E. 1970. Methods for sensory evaluation of food. Food research institute, Canada Dept. Agric. Publ. 1284. Ottawa. 

flour dough and sensory properties of pan bread

Larsson, H. and A.C. Eliasson, 1996. Phase separation of wheat flour dough studied by ultracentrifugation and stress relaxation. 2 . Influence of mixing time, ascorbic acid, and lipids. Cereal Chem. 73, 25-31.

Leon, A., Duran E. and de Barber B., 1981. Firming of starch gels and amylopectin retrogradation as related to dextrin production by alphaamylase. Food Research and Technol. 205, 131-134.

Martin, M. and Hoseney R., 1991. A mechanism of bread firming ii. Role of starch hydrolysis enzyme. Cereal Chem. 68, 503-507.

Martinez-Anaya, M.A. and JimenezT., 1997. Functionality of enzymes that hydrolyze starch and non-starch polysaccharide in bread making. Food Research and Technol. 205, 209214.

Meilgaard, M., Civille O.V. and Carr B.T., 1991. Sensory attributes and the way we perceive them. In: Sensory evaluation techniques. pp. 7-22. CRC Press, Boca Raton, U.S.A.

Miyamoto, Y. and Nishimura K., 2006. Production of thiol radical on a peptide derived from wheat protein by superoxide anion radical. Cereal Chem. 83, 472-477.

Palacios, H.R., Schwarz P.B. and D'Appolonia B.L., 2004. Effect of $\alpha$-amylases from different sources on the retrogradation and recrystallization of concentrated wheat starch gels: relationship to bread staling. J. Agric. Food Chem. 52, 5978-5986.

Pandey, A., Nigam P., Soccol C.R., Soccol V.T., Singh D. and Mohan R., 2000. Advances in microbial amylases. Biotechnol. Appl. Biochem. 31, 135-52.

Patel, M.J.; Ng J.H.Y.; Hawkins W.E.; Pitts K.F. and Chakrabarti-Bell S., 2012. Effects of fungal $\alpha$-amylase on chemically leavened wheat flour doughs. J. Cereal Sci. 56, 644-651.

Paucean, Adriana, Simona M. Man and Sonia A. Socaci, 2016. Wheat germ bread quality and dough rheology as influenced by added enzymes and ascorbic acid. Studia Universitatis Babes-Bolyai Chemia. 2, 103-118.

Pons, M. and Fiszman, S.M. 1996.Instrumental texture profile analysis with particular reference to gelled systems. J. Texture Study. 27, 597624.

Raffo, A., Antonella Pasqualone; Sinesio F., Paoletti F., Quaglia G. and Simeone R.,
2003. Influence of durum wheat cultivar on the sensory profile and staling rate of Altamura bread. Euro. Food Research and Technol. 218, 49-55.

Rouau, X., El-Hayek, M.L. and Moreau, D. 1994. Effect of an enzyme preparation containing pentosanases on the bread making quality of flours in relation to changes in pentosan properties. J. Cereal Sci., 19, 259-272.

SAS, 2000. SAS/STAT User's guide Release 8.01 Ed. SAS Institute Inc., Cary NC, USA.

Shah, Amita R., Shah, R.K. and Datta Madamwar, 2006. Improvement of the quality of whole wheat bread by supplementation of $x y$ lanase from Aspergillus foetidus. Bioresource Technol. 97, 2047-2053.

Sigma Plot Program, 2014. Version 13.0, Build 13.0.0.83, Systat Software Inc. LEAD TOOLS, DUNDAS SOFTWARE Ltd., WP cubed Gmbh, Germany.

Tilley, K.A., Benjamin, R.E., Bagorogoza, K.E., Okot-Kotber, B.M., Prakash, O. and Kwen, H. 2001. Tyrosine cross-links: molecular basis of gluten structure and function. J. Agric. and Food Chem. 49, 2627-2632.

Tong, Q., Zhang, X., Wu, F., Tong, J., Zhang, P. and Zhang, J. 2010. Effect of honey powder on dough rheology and bread quality. Food Research International. 43, 2284-2288.

U.S. Food and Drug Administration, 2006. Food Additive Status List. URL:http://www.cfsan.fda.gov/ wdms/opa-appa.html\#ttnA.

Van der Maarel, M.J.E.C., van der Veen, B., Uitdehaag, J.C.M., Leemhuis, $H$. and Dijkhuizen, L. 2002. Properties and applications of starch-converting enzymes of the $\alpha$ amylase family. J. Biotechnol. 94, 137-155.

Windish, W.W. and Mhatre, N.S. 1965. Microbial amylases. In: "Advances in Applied Microbiology". Wayne, ed. vol. 7, pp. 273-304. Academic Press, New York, U.S.A.

Yamada, Y. and Preston, K.R. 1994. Sponge and-dough bread-effects of oxidants on bread and oven rise properties of a Canadian red spring wheat patent flour. Cereal Chem. 71, 297-300.

Ziobro R., Gambus H., Nowotna A., Bala-Piasek A. and Sabat R., 1998. Starch extrudates as a source of low molecular dextrins slowing down bread staling. Zywn. Technol. Jakosc. 17, 251-258. 